$$
\begin{aligned}
& \text { قسم الباثولوجيا }
\end{aligned}
$$

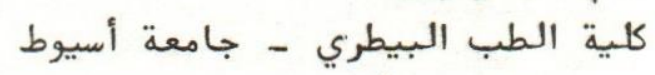

$$
\begin{aligned}
& \text { رئيس القسم : .أ •ـ/ حمدي عبد العزيز سالم السيوط }
\end{aligned}
$$

$$
\text { في أنسجة الرئة لأنواع من الدواريف والعظام في غير مواضعها المهاجية والأجنبية }
$$

$$
\text { محمود عبدالظاهر ، علام نفادي }
$$

في دراسة هستولوجية لريتي كتاكيت خالية من الأمراض من سلالات أجنبية ومصرية

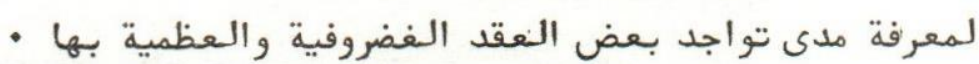

وجد أنها توجد في اللجهورن الأبيض بنسبة ع؟٪ وفي الهيبرد نسبة 7 ا٪ وفــــي

$$
\text { الدقي •ع بنسبة r٪ بينما لا توجد في الكتاكيت الفيومي • }
$$

وقد نوقشت النظريات المختلفة التي تفسر وجودها في الرئة ووجد أن هذه العقـد

الفضروفية والعظمية لا تتكون نتيجة لحالات مرضية ولكنها من المحتمل انها نتجت عسن فئن

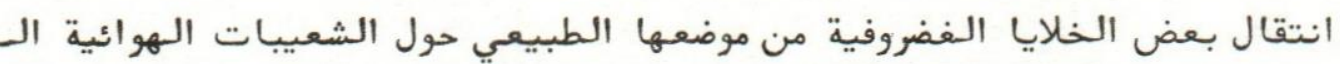

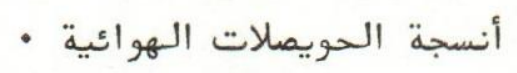


Dept. of Pathology,

Faculty of Vet. Med., Assiut University,

Head of Dept. Prof. Dr. H.A. Salem.

\title{
INCIDENCE OF ECTOPIC PULMONARY CARTILAGE AND BONE IN FOREIGN AND NATIVE BREEDS OF CHICKEN \\ (W'ith 4 Figs.)
}

\author{
By \\ A.Z. MAHMOUD and A. NAFADY \\ (Received at. 15/10/1987)
}

\begin{abstract}
SUMMARY
The occurence and morphological appearance of ectopic pulmonary cartilage and bone in chickens was studid. Its incidence was shown to vary in different breeds of chickens. These Cartilage and bone was observed in 3 week old chicks up to 15 weeks old. The previous theories of the ectopic pulmonary cartilage genesis were discussed. It was concluded that they do not originate from disease process, but are probably abnormal embryonic induction of mesenchymal or cartilaginous germ cells displaced from bronchi.
\end{abstract}

\section{INTRODUCTION}

A cartilaginous and ossified foci were occasionally seen in the lungs of laboratory mammals, INNES, et al. (1956) and domestic chickens, BORST, et al. (1976). In chickens they attributed the presence of these foci to inhalation of dietary bonemeal during process of feeding. On the other hand NEWBERNE and MCEUEN (1957) assumed that these cartilaginous and bony tissue in the domestic chickens resulted from metaplastic changes of fibrosed pulmonary tissue in birds. While JULIAN (1983), WIGHT and DUFF (1985) suggested that the condition is metastasis of cartilage from dyscondroplastic long bone.

In the avialuble literature little is known about these ectopic structures. During experimental studies in some diseases of chickens, a cartilaginous and bony tissue was observed in unusuall sites in lungs, of different breeds of chickens for this reason, this study was design to collect lung tissue of normal chickens and examine it by light and electrone microscope for detection of the presence of cartilage and bone in the lung of foreign and native breed chickens.

\section{MATERIAL and METHODS}

All birds included in these studies were used as a control birds in previous experimental studies:

1 - 100 white leghorn chicks aged 3-15 weeks from department of poultry science Auburn University, Auburn Alabama USA.

2 - 100 Hybrid chick (used for meat production), 180 Dokky 4 chicks and 160 Fayoumi chicks aged 4-15 weeks from department of Veternary Pathology Assiut University, 


\section{MAHMOUD and NAFADY}

Samples were taken from different parts of the lung, fixed in Bouin's solution, procesed for paraffin sections as usuall and stained with haematoxylin and eosin, Masson trichrome and Von kossa stain (LILLIE, 1965). Another small block $2 \times 2 \mathrm{~mm}$ of lung tissue were taken from different parts of the lung, fixed in 5\% glutaraldhyde and processed for semithin and ultrathin sections using Epon 112 as an embedding media. The semithin sections were staind by toluidine blue and the ultrathin sections contrasted by using uranyl acetate and lead citrate and examined by Zelss EM $10 \mathrm{c}$.

\section{RESULTS}

The incidence of hard cartilaginous tissue in the lung sections of different breed chicks were $24 \%$ in white leghorn chicks $16 \%$ in hybird chicks, $3 \%$ in Dokky 4 chicks and $0 \%$ in Fayoumi chisks. Microscopicaly the cartilage and bone varied in its size and position within the pulmonary lobules. They were usually roughly circular in outline. In young aged chicks ( 3 weeks old) this structure was formed of few number of chondroblasts imposed in hamogeneous hyaline matrix (Fig. 1). The number of cells forming this structure and size of it in the sections were increased with the increases of the age of chickens. The foci has no capsule of connective tissue and they had a normal regular histoid arrangment. (Fig. 2). Also evidence of mitotic division of the cells forming this cartilaginous structures could be observed. Ultrastructurally the carilaginous foci formed by chondroblasts surrounded by fine granuler of moderately electron dense matrix. The chondroblast appeared viable and highly active. The evidence of activation were in the form of well developed abundant rough endoplasmic reticulam, numerous mitochondriae and presence of cytoplasmic vacolues (Fig. 3). The foci of bony structure begin to appear at 10 weeks old. They were observed singly in same microscopic field of the lung and never multile (Fig. 4). They consists of dense osteiod material stained green with peripheral red rim with Masson trichrome, purble with haemotoxlin and eosin and black with Von Kossa stain.

\section{DISCUSSION}

Presence of cartilaginous and bony nodules in the lung of white leghorn, hybrid and Dokki 4 chickens was confirmed in our results but in Fayoumi chickens could not be detectd. It is intersting that the highst incidence occured in Foreign breeds as it reached in white legharn $24 \%$ and $16 \%$ in hybrid chicks. While in native chicks it reached $3 \%$ in Dokki 4 and $0 \%$ in Fayoumi breeds.

INNES, et al. (1956) and JULIAN'S (1983) suggested that the bone and cartilaginous nodules reached the lungs by inhalation of particles of dietary bonemal. According to this suggestion, these particles which may act as a foreign body, a tissue reaction against these particles could be seen. Our findings revealed complete abscence of any foreign body reaction. The cells forming these nodules are viable and hyperactive to form its hyaline matrix and this perhaps did not indicate their inhalation.

Although NEWBERNE and MCEUEN (1957) suggested that presence of cartilage and bone nodules in the lung tissue resulted from metaplasia of fibrosed pulmonary tissue, BOREST, et al. (1976) stated that there is no relation between these nodules and disease process. Complete abscence of any pathological changes or fibroses in the lung tissue surrounding these nodules indicate that, these nodules not resulted from metaplastic changes.

Assiut Vet.Med.J. Vol. 20, No. 39, 1988. 


\section{ECTOPIC PULMONARY CARTILAGE IN CHICKEN}

Our openion was in agreement with the suggestion of JULIAN'S (1983) and wight and DUFF. (1985) that these rodules are genetically associated and resulted by metastasis and displacment of chondrognic germ cells during embryonic development. As these nodules were not encupsulated and they had a normal regular histoid arrangment so they were not chondroma JONES and HUNT (1983). The bony tissue was appeared some what latter than cartilaginous tissue. These bony nodules seemed to be resulted from ossifection of the cartilaginous nodules.

From this study we can conclude that the incidence of the presence of cartilaginous and bony foci in lung tissue greatly variéd among different breeds of chicks. It was also concluded that this cartilaginous foci resulted from displaced cartilaginous germ cells from adjcent bronchi.

\section{REFERENCES}

Borst. G.H.A.; P. Zuant; H.W.M.A. Mulink and C. Vroecf (1976): Bone structures in avian and mammalian lungs. Vet. Pathol. 13: 98-103.

Junes, J.M.; Yevich, P. and Donati, E.J. (1956): Citted by wight and Duff. (1985): Archives of Pathology. 61, 401-406.

Jones, T.C. and Munt, R.D. (1983): Veterinary pathology 5th. edn. lea \& Febiger. Philadelphia. Julian, R. (1983): Foci of Cartilage in the lung of broiler chickens. Avian Dis., 27, 292-295. Lillie, R.D. (1965): Histopathologic technic and practical histochemistry 3rd. edn. New York. McGrow-Hill.

New berne, P.M. and McEuen, C.L. (1957): Studies on drug toxicity in chicks 4. The influence of various levels of nitrofurazone on growth and development of chicks. Poultry Science 36: 739-743.

Assiut Vet.Med.1. Vol. 20, No. 39, 1988. 

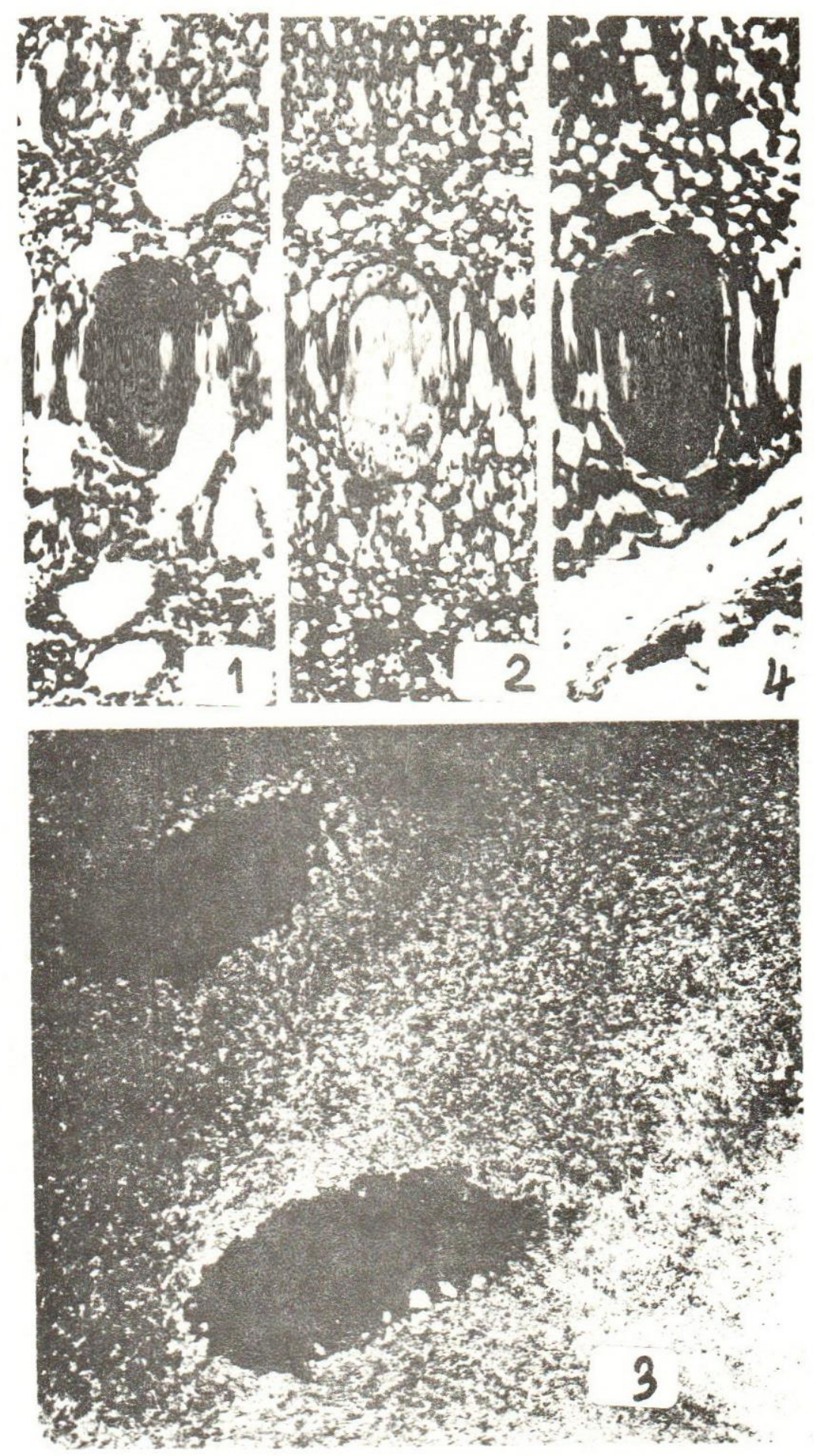

Fig. (1): Foci of cartilage in the pulmonary lobule of 3 weeks old white leghorn chick $H \& E(16 \times 12.5)$.

Fig. (2): Cartilaginous nodules within the lung parenchyma of 7 weeks old hypird broilers chichens $H \& E(16 \times 12.5)$.

Fig- (3): Electronmicrograph of cartilaginous foci in the lung Showing well active chondroblast and hyalin motrix (17 600).

Fig. (4): Foci of bone in the lung parechyma of 7 weeks old white leghorn chickens. $H \& E(16 \times 12.5)$. 
